\title{
ANALYSIS OF EARPHONE SWAB MITOCHONDRIAL DNA AS AN ALTERNATIVE MATERIAL FOR IDENTIFICATION EXAMINATION
}

\author{
Ahmad Yudianto ${ }^{1,2,3}$, Yeti Eka Sispitasri ${ }^{1,3}$, Nola Margaret ${ }^{1}$ \\ ${ }^{1}$ Department of Forensic Medicine \& Medicolegal, Faculty of Medicine, Universitas Airlangga \\ ${ }^{2}$ Human Genetic Group Institute Tropical Disease, Universitas Airalangga \\ ${ }^{3}$ Program Magister Ilmu Forensik Sekolah Pascasarjana, Universitas Airlangga
}

\begin{abstract}
ABSTRAK
Identifikasi termasuk sidik jari, properti, kesehatan, gigi, serologi dan metode eksklusi. Dalam perkembangannya, metode identifikasi menyebabkan forensik molekuler, perkembangan bidang ilmu baru sejak 1980-an, dikenal sebagai sidik jari DNA. Spesimen secara luas digunakan dalam uji DNA untuk identifikasi bercak darah/darah, bintik-bintik air mani, penyeka vagina, penyeka bukal dan tulang. Selain spesimen ini, benda terakhir yang sering digunakan pelaku/korban yang dapat digunakan, seperti alat bantu dengar (headset/earphone). Dalam penggunaannya, earphone yang melekat pada kulit telinga luar; dengan demikian, kotoran telinga yang diduga menempel pada perangkat. Sampai saat ini, di Indonesia identifikasi individu dilakukan melalui penyeka earphone/headset dengan menggunakan metode DNA profiling. Secara khusus, DNA mitokondria belum banyak digunakan untuk identifikasi. Penelitian ini adalah laboratorium eksperimental. Earphone yang telah digunakan selama 3 hari ditempatkan di suhu ruangan selama 1, 7, 14 dan 20 hari. Hasil penelitian menunjukkan bahwa faktor lingkungan terhadap durasi paparan memiliki efek dari penurunan yang signifikan dalam tingkat DNA dari hari 1 sampai hari 20. Hanya 126-bp mtDNA (HVS II) terdeteksi pada sampel dari hari 1 dan dilanjutkan dengan runtut. DNA mitokondria memiliki daya tahan yang lebih baik dan jumlah yang relatif lebih tinggi dari salinan daripada DNA nuklir. Hal ini menyebabkan kemungkinan lebih besar untuk sukses dalam amplifikasi, mengingat jumlah salinan DNA mitokondria yang lebih tinggi dan fakta bahwa DNA mitokondria adalah lokus tunggal yang memungkinkan rekombinasi.(FMI 2016;52:169-173)
\end{abstract}

Kata kunci: earphone penyeka, identifikasi, $m t D N A$

\begin{abstract}
Identification include fingerprint, property, medical, dental, serologic and exclusion methods. In the development, identification methods led to molecular forensics, a new field of science evolving since the 1980s, known as DNA fingerprinting. Specimens widely used in DNA assay for identification are blood spots/bloods, semen spots, vaginal swabs, buccal swabs and bones. In addition to these specimens, the last objects often used by the perpetrators/victims can be used, such as hearing aids (headsets/earphones). In its use, earphones are attached to the outer ear skin; thus, the earwax is suspected to adhere to the device. To date, in Indonesia personal identification is performed through swabs of earphones/headsets using the DNA profiling method. In particular, mitochondrial DNA has not been widely used for identification. The present study was of laboratory experimental. Earphones which have been used for 3 days were placed in room temperature for 1, 7, 14 and 20 days. Results showed that the environmental factor of exposure duration had an effect of a significant decrease in the levels of DNA from day 1 to day 20. Only 126-bp mtDNA (HVS II) was detected on the samples of day 1 and continued with sequencing. Mitochondrial DNA has better durability and relatively higher number of copies than those of nuclear DNA. This leads to greater possibility of success in amplification, given the higher number of mitochondrial DNA copies and the fact that mitochondrial DNA is a single locus that allows recombination. (FMI 2016;52:169-173)
\end{abstract}

Keywords: earphone swabs, identification, $m t D N A$

Correspondense: Ahmad Yudianto, Departemen Ilmu Kedokteran Forensik \& Medikolegal, Fakultas Kedokteran, Universitas Airlangga, Jl Prof Dr Moestopo 47, Surabaya 60131. e-mail: yudi4n6sby@yahoo.co.id

\section{INTRODUCTION}

Methods of identification in forensic medicine which include fingerprint (dactyloscopy), property, medical, teeth, serology and exclusion method. Fingerprints and dental is the most specific method for personal identification. In the expansion of identification methods lead to molecular forensics. Forensic Molecular is an emerging field of science since the early 1980s more methods known as: DNA fingerprinting. This method was first introduced by Jefreys in 1985, is part of the science of forensic medicine which utilizes knowledge of medicine and biology at the molecular level or DNA (Deoxyribonucleid acid).

DNA is the smallest unit of heredity and are all living creatures ranging from microorganisms to higher organisms such as humans, animals and plants. According 
Notosoehardjo (2000), each network has a different DNA content depending on the structure and composition of the cell. Network with many nucleated cells and little connective tissue generally have high levels of DNA. Selection of the organ to be isolated DNA to forensic case analysis is important, sometimes the circumstances that had rotted away or just stay up bones. Every part of the human body can be taken as a specimen because every cell in the body has the identical DNA sequence, where a child is basically receive the same amount of genetic material from the mother and biological father (the laws of Mendelian inheritance).

During this specimen that is widely used in DNA testing to identify, is a specimen of blood spots/blood, semen patches, vaginal swab, buccal swab and bone (Kusuma 2004). At the crime scene/crime scene trace evidence would be obtained biology. In addition to the biological trace evidence among objects that frequently used the last time the perpetrator or the victim. One of them that hearing aids are now more prevalent mobile phone which is a headset or earphone. Headset/earphone audio is an electronic device, which is used in mobile phones or MP3 voice heard. In use earphones attached to the skin so that the outer ear cerumen suspected that stick to the tool. Earlier in Japan has done research on the subject, Seo et al (2002) in his research is to do forensic identification through the wax material attached to the earphones used by offenders. Only until now there has been a lot of research that specifically describes the effectiveness of using swab earphones for use as identification. Other studies that Sosiawan et al (2004) investigated the use swab efektifiatas cerumen in paternity tests.

Should be developed inspection of objects obtained from the crime scene one of the earphone tool. So this research is expected to provide answers on matters relating to the use of specimens came from earwax that menenpel the earphone/earphone swab in particular forensic identification identifikas gender. So the discovery of the items at the crime scene would be a great contribution in uncovering crime.

DNA identification that involves somatic chromosomes, the comparison used is a father and a mother. While the examination of mitochondrial DNA, a comparison used is relative in the maternal line. The wide variety of comparators can be used according to the type of cases, for example, can be used comparative grandparents, cousins and others, but the course of analysis used a slightly different (Syukriani 2012). In mitochondrial DNA (mtDNA) humans have a genetic trait that distinguishes it from the nuclear genome. Mitochondrial DNA is passed down only through maternal lines without recombination (maternal inherited). Mitochondrial DNA in the daughter cells entirely donated by the mother and the sperm did not contribute (Campbell 1996). The uniqueness of this inheritance system has been utilized in various fields, namely the determination of kinship, the study of evolution and global migration of modern humans, forensic and identification of genetic disease (Wallace 1997).

Until recently in Indonesia personal identification through a swab on the earphone/headset with methods of DNA analysis (DNA Profiling) in particular through mitochondrial DNA has not been done, so this research may provide answers on matters related to the effectiveness of the use of swab earphone as material identification forensics.

\section{MATERIAL AND METHODS}

This type of research that is observational laboratories. Air-phone that has been used for 3 days, placed in room temperature span of $1,7,14$ and 20 days. through the Dloop region of mitochondrial DNA of 126 bp (nt 34159. HVS II), with a cross-sectional survey research design. The subjects of this study is a tool earphones that have been used/sticking to the ear canal for 3 days and stored for 1 day, 7 days, 14 days and 20 days (@ 2 samples), where research on Human Genetic Study Group, Institute of Tropical Disease, Airlangga University Campus C Mulyorejo. Materials research is swab earphones, with the material for DNA extraction is DNAzol Reagent, Solution 100\% and 70\% ethanol. While the material for the PCR are PCR Mix (12.5 ul) consisting of dNTP (ATP, CTP, TTP GTP), $\mathrm{MgCl} 2$ and Taq polymerase, DW sigma (Nuclease Free water), Primary mtDNA 126 bp (nt 34-159. HVS II) (AFDIL, Gabriel et al 2001): 5'-GGG AGC TCT CCA ATT TGG TGC TA-3 ' TAA TAG 5'-AAA GAT GAG ATC GCA GGA-3 '

\section{RESULTS}

\section{Levels of DNA samples}

This study begins with the treatment of the sample which is 8 pieces tool earphones that have been used/ stuck in the ear canal for 3 days and then the tools are stored at room temperature respectively within: 1 day, 7 days, 14 days and 20 days. Then followed each group time (@2 pieces tool earphones) with extraction/DNA isolation from swab samples earphones with DNAzol method. The results of the sample DNA extraction followed by measurement of DNA samples using a UVVisible Spectrophotometer at a wavelength of $260 \mathrm{~nm}$ 
( $\lambda$ 260). The results of measurements of DNA after DNA isolation from swab earphone prior to PCR amplification (Polymerase Chain Reaction) as follows:

Table 1. Levels of DNA in the sample

\begin{tabular}{cccc}
\hline Samples & & $\begin{array}{c}\text { DNA Levels } \\
(\mu \mathrm{g} / \mathrm{ml})\end{array}$ & $\begin{array}{c}\text { Average Levels } \\
(\mu \mathrm{g} / \mathrm{ml})\end{array}$ \\
\hline Day 1 & 1 & 23.24 & 21.67 \\
\hline \multirow{2}{*}{ Day7 } & 2 & 20.09 & 14.70 \\
\hline \multirow{2}{*}{ Day 14 } & 1 & 16.05 & 8.14 \\
& 2 & 13.35 & 6.60 \\
\hline Day 20 & 2 & 7.25 & \\
\hline
\end{tabular}

From the graph above, the decreased levels of DNA from the swab samples earphones on a long exposure time. The longer described getting down the levels of DNA, which is the average on day $1: 21.67 \mu \gamma / \mathrm{ml}$, day 7 : $14.70 \mu \mathrm{g} / \mathrm{ml}$, day $14: 8.14 \mu \mathrm{g} / \mathrm{ml}$ and day $20: 6.60 \mu \mathrm{g} / \mathrm{ml}$.

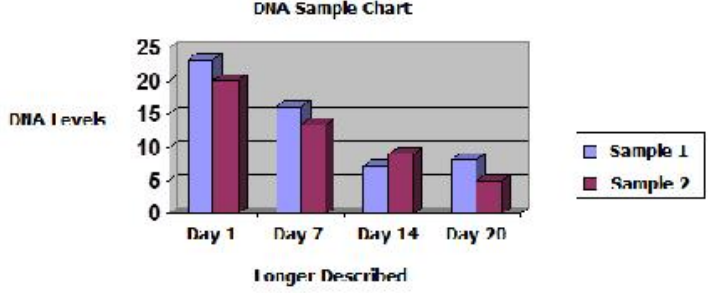

Fig. 1. Levels of DNA sample chart

\section{Results amplification Polymerase Chain Reaction (PCR)}

The process of amplification Polymerase Chain Reaction (PCR) which begins with the preparation of DNA template through the process of cell lysis earphone swab using extraction kit (DNAzol). Results of the extraction/isolation of DNA is apparently capable of producing cell lysate in the form of DNA that is ready to be used as a PCR template. The process of PCR using the area Hipervariable region (HV) II D-Loop (nt 59-134), has been given a bright band sized $126 \mathrm{bp}$ as shown in Figure 1.

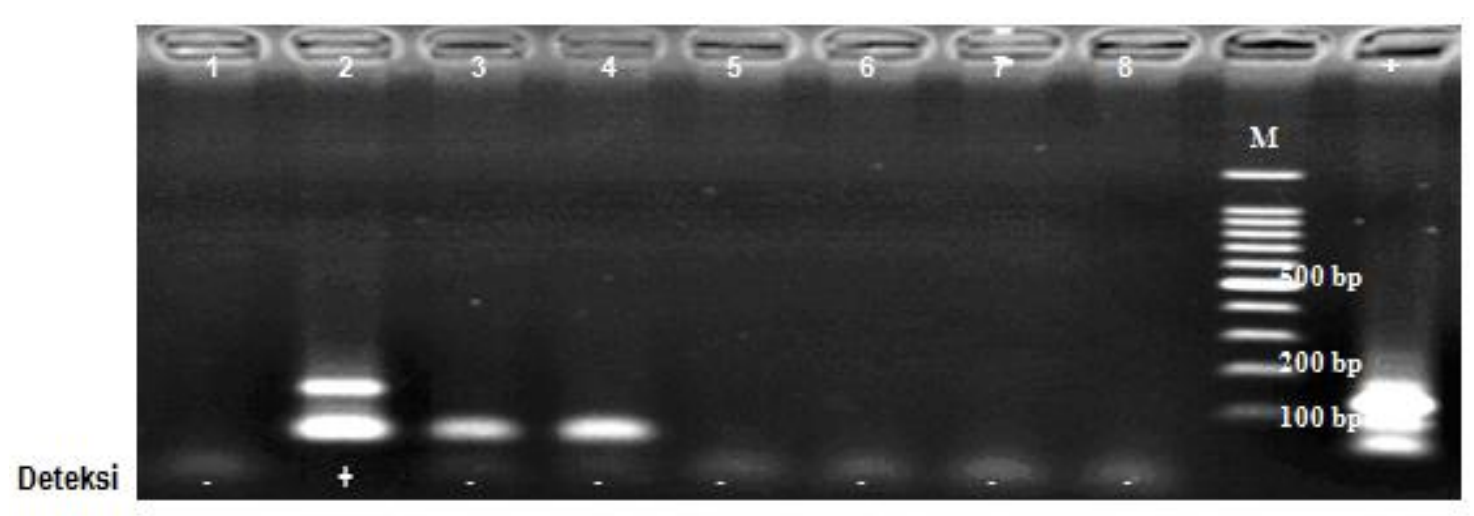

Fig 2. Results of 126 bp PCR product visualization swab samples earphones, (M) marker, (+) positive control, $(1,2)$ : the sample 1, (3.4): sample day 7 (5.6): samples of the 14 (7.8): 20-day sample

In Figure 1 above shows the appearance of a band at $126 \mathrm{bp}$ that the primers used are specific to just stick to the expected position (nt 59-134). The PCR process is carried out to amplify $126 \mathrm{bp}$ D-loop region using primer pair M1 and M2. PCR products were analyzed by agarose gel electrophoresis $1.2 \%(\mathrm{w} / \mathrm{v})$. The visualization results showed that only sample 2 can still detect the positive $(+)$.

\section{Sequencing}

Sequencing PCR fragment $126 \mathrm{bp}$ region of mtDNA Dloop earphone swab samples conducted by Sanger dideoxy method using Automatic DNA Sequencer is based on a method Labeling Dye Terminator. 126bp fragment sequencing PCR products is done by using fragments of amplification product directly without going through the process of cloning, the process is called direct sequencing. This method is used, because the process is fast and the result is a dominant nucleotide sequences of DNA PCR amplification results. To determine the nucleotide sequence of the PCR product size $126 \mathrm{bp}$ used in the sequencing reaction primer M1 (forward), this study was able to determine the nucleotide sequence of the D-loop region of mtDNA samples as shown in the picture below. 


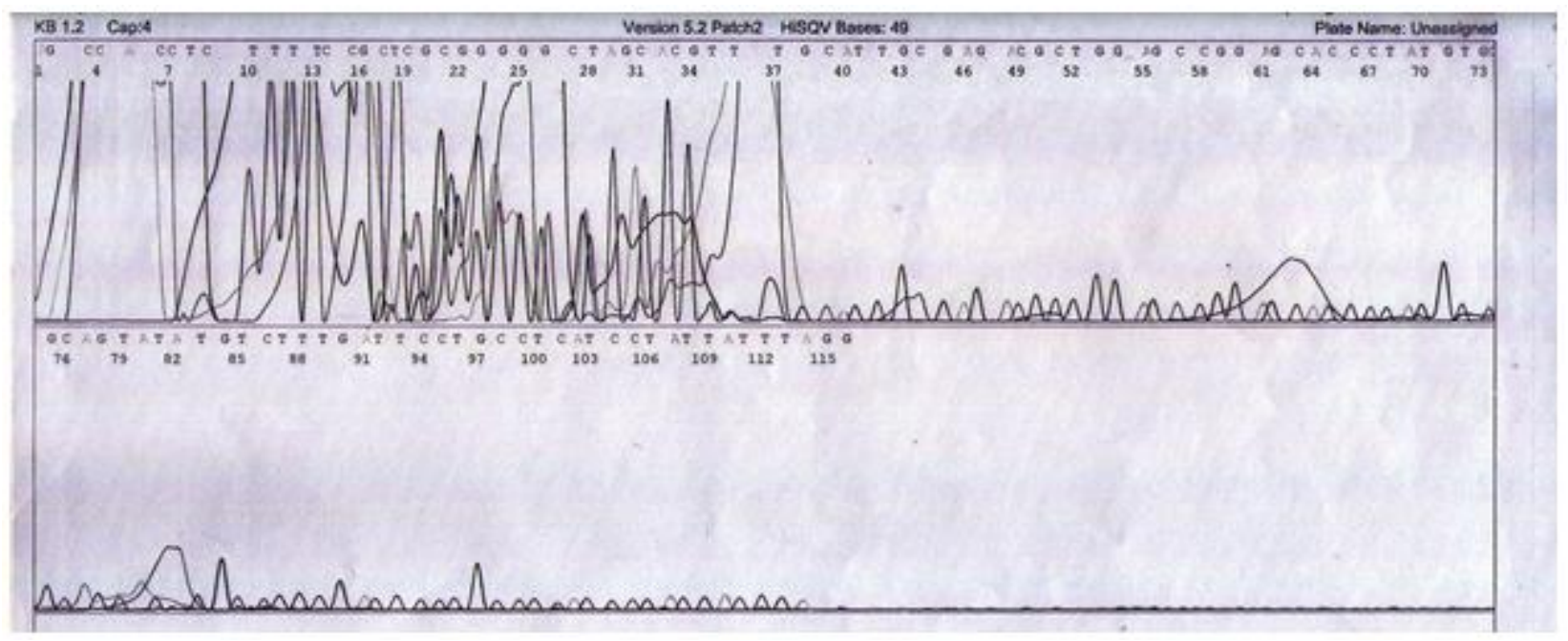

Fig. 3. electropherogram sequencing results

The figure shows the sequencing electropherogram, the difference in color of the line, ie, black to guanine $(\mathrm{G})$, blue for Cytosin (C), the red color to TYMIN (T) and green colors to adenine (A).

\section{DISCUSSION}

From this research, the effects of the environment in terms of temperature and long exposure to the securities in this study prove their influence on the measurement of DNA contained. It is seen from the results of measurements of DNA by spectrophotometry showed decreased levels of the DNA swab samples earphone significantly from day 1 to day 20. Only in the samples to one which still shows detected at $126 \mathrm{bp}$ mtDNA HVS II and continued sequencing.

The results of this study also shows the environmental effects in terms of the length of time of exposure to the effects in this study prove their influence on the measurement of DNA contained. It is seen from the results of measurements of DNA by UV spectrophotometry showed decreased levels in samples of urine patches are stored in room temperature and places with high humidity from day $1,7,14$ to day 20 there were any significant decline. Environmental factors that cause DNA degraded or degraded DNA. This degradation can be fast or slow, it depends on factors that influence and time of exposure. DNA damage daibagi into two types: the damage from the inside, eg caused by reactive oxygen species (ROS) and damage from external factors, such as temperature, humidity etc.
According to Sullivan (1992), mitochondrial DNA endurance is better than nuclear DNA it has a relatively large number that has a chance of success in the amplification process is greater, given the number of copies of mitochondrial DNA more. This corresponds to the opinion Parson and Coble (2001), the copy number of mtDNA has more about 500-2000 copies per cell, compared to nuclear DNA which is only two copies per cell and mitochondrial DNA is a single locus that the recombination. Mitochondrial DNA thus have the nature of the power of discrimination is lower than nuclear DNA. Thus mitochondrial DNA is an alternative when faced with the nuclear DNA is degraded condition of the complex or severe. However, if the use of a standard primer on the STR is not able to detect, then the alternative perform primary redesign to reduce amplicon size before using mtDNA.

On the earphones that have been used for 3 days is attached at room temperature for a maximum of 20 days (according to the old Code of Criminal Procedure detention period in the process penydikan). In this study indicate that environmental influences affect the levels of DNA. As is known environmental factors such as humidity and temperature of the environment is affecting the condition of DNA that are used as ingredients in the field of forensic DNA identification, as well as on other DNA testing in the field.

\section{CONCLUSION}

From the results and discussion of this research can be concluded that there are external factors that affect the environment and the long exposure quantity and quality of DNA from the swab eraphone, but still can be an 
alternative material in forensic identification. From the results of PCR samples only 1 day to 1 which still shows detected in mtDNA HVS II 126 bp (nt nt 34-159) and the results sekensing well. While the sample days 7 , 14 and 20 are not detected by $2 \%$ agarose elektroforese. MtDNA examination of swabs earphone can only be done one day after the tool left behind in the open space.

\section{REFERENCES}

Anderson,S.,et al.1999. Sequence and organization of the human mitochondrial genom, Nature, 290,457-465

Affoed RL and Caskey CT,1994.DNA analysis in Forensic disease and animal identification. Curr Opin Biotech. 5:29-32

Butler,JM,2001, STR Analysis for human testing,STR Typing.Current protocols in Human Genetic Unit.14.8,pp 1-37

Butler,JM, 2003, Forensic DNA Typing, Academic Press, Sandiego-Florida, page 28-30, page 59-96.

Idries, A.M, 1997, Pedoman Ilmu Kedokteran Forensik, Edisi pertama, Jakarta, Penerbit Binarupa Aksara.

Jackson M Kelly, 1990, The Polymerase Chain Reaction, Simposium DNA Probing: Teknik dan Penerapan Klinis, HKKI.

Jusuf M, 2001, GENETIKA I Struktur \& Ekspresi Gen, Sagung Seto, Jakarta

Lewis R, 2001,Human Genetics Conception and Application, 2nd Ed Wm.C.Brown Publishers, Toronto, page139-180.
Mark A.F, 1991, Forensik DNA Technology, Lewis Publishers inc.

Murray et al, 1997, Biokimia Harper, edisi 24, EGC, hal 366-370

Muladno, 2002, Seputar tehnologi rekayasa genetik, Edisi pertama, Bogor, Pustaka.

Notosoehardjo I,2001,DNA Forensics ;Paternity test, Past, Present, and Future,J.For.Scien,VIII,pp 34-45.

Notosoehardjo I, Kuntaman,2002, Teori dasar dan penerapan Praktis PCR,TDC Universitas Airlangga, hal 1-11.

Peter P.B,2004,Teri's Find a forensic study in authentication, Biro Fine art restoration and forensic studies in art. Pp 23-25.

Syukriani Y, 2012. DNA Forensik. PT Sagung Jakarta.

Terry Melton, and Kimberlyn Nelson, 2003. The case of degraded DNA: mtDNA ancient analysis to the rescue;Mitotyping Technologies, LLC, State Coll. PA

Wallace, D.C. 1997, Mitochondrial DNA variation in human evolution, degenerative disease and aging. American Journal of Human Genetic.57,201-223

Watson et.al, 1986, Molecular Biology of The Gene, 4nd.Ed. Cummings Publishing Company,Inc.

Zainuddin M, 2000, Metodologi Penelitian, Kumpulan kuliah Pascasarjana UNAIR

Yasuhisa Seo, Taketo Uchiyama, Hirokazu Matsuda, Kenshi Shimizu, Yasunari Takami, Tasuo Nakayama, Keiichi Takhama, 2002, Mitochondrial DNA an STR Typing of Matter adhering to an earphone, Journal of Forensic Sci; 47(3):605-608 